\title{
A Case Study on Assessment Performance and Energy Efficient Recommendations for Industrial Boiler
}

\author{
Pratik M. Joshi ${ }^{1}$, Shekhar T. Shinde ${ }^{2}$, Kedarnath Chaudhary ${ }^{3}$ \\ ${ }^{1}$ Student, ${ }^{2}$ Assistant Professor, ${ }^{3}$ M.Tech, \\ Mechanical Engineering, Bharati Vidyapeeth (Deemed to be University), College of Engineering, \\ Pune, Maharashtra \\ Corresponding Author: Shekhar T. Shinde
}

\begin{abstract}
As India is a developing country, industrialization is increasing day by day and there is a great need for industry energy audit. Audit helps to maintain and save energy from being wasted and helps in achieving highest efficiency of industrial equipment. This paper contains an actual industry audit report on boiler performance. This paper contains a report on Thermal analysis of boilers, thermal skin heat loss of boilers, $\mathrm{O} 2$ percentage control in flue gases to standard values, effect of coal additive, etc. This paper also contains a report on waste heat recovery options for thermal boiler, flue efficiency monitor, infrared thermometer, ultrasonic peak detector IR thermal imager. These equipment are used for energy assessment of boilers. Thermography survey of boiler surface is carried out to estimate the radiation and the other losses and the result of this total annual saving after insulation repairing or maintenance is Rs.8.48 lakh and investment is around Rs.6.31 lakh. Economizer performance of both the ISGEC and Thermax boiler can be improved with the help of suggested measures. It will help to save approximately rupees Rs.38.42 Lakh annually and investment on maintenance cost is negligible. In short, this paper deals with assessment of all boilers, evaluates their efficiencies and losses to identify energy saving opportunities and presents them in a report with their payback periods.
\end{abstract}

Keywords: Energy, Energy audit, assessment, boiler.

\section{INTRODUCTION}

Boiler is most energy consumable equipment as compared to any other equipment's used in industry and there is great need of energy assessment of boiler on every early. In this paper taking $18 \mathrm{TPH}$ Thermax boiler, 18TPH ISGEC boiler, and 12TPH FBC boiler for assessment. Through sincere and carefully analysis new model is proposed for boiler industry. In this audit during the boiler assessment advanced equipment's are used and result of this concludes accurate analysis of boiler performance. This paper contains an actual industry audit report on boiler performance. For assessment of boiler Thermal analysis of boilers, thermal skin heat loss of boilers, $\mathrm{O} 2$ percentage control in flue gases to standard values effect of coal additive, etc. tests are performed on boiler.

\section{Methodology for Energy Analysis of Boilers}

1. During audit we have record output and input parameters of both boilers. Our thermal experts undertook physical inspection of above boilers along with discussions about performance with respective operating staff. [1-2]

2. We used recorded flue gas parameters and actual proximate analysis results of the coal for efficiency calculations and then to locate losses. [3] 
Pratik M. Joshi et.al. A case study on assessment performance and energy efficient recommendations for industrial boiler

3. Detail analysis of all the boilers is shown below which can be compared mutually as as with standards.

4. We have used following methodology for this analysis.

\section{Tests Conducted-}

a. A sample trial on both the boilers for sufficient time period including precise measurement of steam quantity and coal supplied.

b. The proximate analysis of the same coal and ash is done to ensure the percentage of various constituents in the same.

c. With the help of proximate analysis results, ultimate analysis parameters were derived and are used to estimate various heat losses.

d. A flue gas analysis is carried out using a high-end flue gas analyzer at outlet of convection zone and chimney sampling point to observe the quality of combustion. e. Infrared Thermography of boiler parts, auxiliaries and steam distribution system is done to inspect the healthiness of insulation and calculate the heat losses due to damage or absence of insulation.

5. With the help of above data, efficiency of both the boilers is calculated by direct method and indirect method.

6. Various losses and operational improvements are identified and categorized them into no cost measures, low-cost measures and high-cost measures.

\section{Objective and the details of the equipment \\ Audit objective}

Assessment of all boilers to evaluate their efficiencies and losses to identify energy saving opportunities and present them in report with their payback periods

\begin{tabular}{|c|c|c|}
\hline \multicolumn{3}{|c|}{ Details of Equipment Used: } \\
\hline Name of the equipment & Make & Use \\
\hline Flue Efficiency Monitor & Technovation & Online monitoring of flue efficiency. \\
\hline Sling type Psychrometer & Dimple & Humidity Measurement \\
\hline Glass type Thermometer & Vertex & Temperature Measurement \\
\hline Infrared Thermometer & HTC & Temperature Measurement \\
\hline Vane type Anemometer & Lutron & Air flow Measurement \\
\hline Ultrasonic Leak Detector & CS Instruments & Inspection of steam traps \\
\hline IR Thermal Imager & Testo & Identification of hot surfaces and its temperature measurement \\
\hline
\end{tabular}

BOILER RATINGS -
\begin{tabular}{|c|l|c|c|c|}
\hline Sr. No. & \multicolumn{1}{|c|}{ Description } & Boiler 1 & Boiler 2 & Boiler 3 \\
\hline 1 & Make & Thermax & ISGEC & Thermax \\
\hline 2 & Rated Capacity TPH & 18 & 18 & 12 \\
\hline 3 & Rated Steam Pressure, Kg/cm 2 & 28.5 & 28.59 & 17.5 \\
\hline 4 & Model & Travelling Grate Type Boiler & Travelling Grate Type Boiler & FBC type Boiler \\
\hline 5 & Fuel & Indian Coal & Indian Coal & Indian Coal \\
\hline 6 & Auxiliaries Electrical Supply & $415 \mathrm{~V}, 3$ Phase & $415 \mathrm{~V}, 3$ Phase & $415 \mathrm{~V}, 3$ Phase \\
\hline 7 & Heating surface area sq.m. & NA & 879 & 446 \\
\hline 8 & Design Rated Steam Temp, ${ }^{\circ} \mathrm{C}$ & 420 & 420 & 208 \\
\hline
\end{tabular}

- Steam generated by travelling grate type boilers is mainly supplied to two backpressure turbines of $1.5 \mathrm{MW}$ and $0.8 \mathrm{MW}$ capacities through a common steam header.

- These boilers generate superheated steam of $27-29 \mathrm{~kg} / \mathrm{cm}^{2}$ pressure.

- Low pressure steam from cogeneration plants at $5-6 \mathrm{~kg} / \mathrm{cm}^{2}$ is utilized for the plant process steam requirement and finally condensate is recovered at 2.5 $\mathrm{kg} / \mathrm{cm}^{2}$ for the boiler feed.

- The daily coal consumption for the boilers is $110-115$ MT i.e., Rs 5 Lacs / day.

- 12TPH FBC type boiler is used to serve the additional process steam requirement which is not continuously used. It can produce steam of $17.5 \mathrm{~kg} / \mathrm{cm}^{2}$ Pressure. The boiler is operated during 
Pratik M. Joshi et.al. A case study on assessment performance and energy efficient recommendations for industrial boiler

maintenance period of above boilers or in case of excess steam demand.

- Condensate recovery of the plant being $80 \%-85 \%$, very less amount of makeup water is added in the system. This helps to minimize blow down below $1 \%$.

- For ISGEC boiler and FBC boiler, coal feeding is controlled with the help of drive which is operated manually based on steam pressure. Thermax boiler does not have a drive control for coal feed.

- Annual coal consumption of the plant for these boilers is around $60 \mathrm{k}-65 \mathrm{k}$ tonnes which costs around Rs. 3235Crores.

- For waste heat recovery, economizer and air pre-heater are provided in the flue gas path of ISGEC boiler whereas for Thermax Boiler only economizer is installed.

For 12TPH FBC boiler, water optimizer as well as air pre-heater are installed which extract maximum possible heat from flue gases.

THERMAL ANALYSIS OF BOILERS -

\begin{tabular}{|c|c|c|c|c|}
\hline Sr. No & Parameters & $\begin{array}{l}18 \text { TPH Thermax } \\
\text { Boiler }\end{array}$ & $\begin{array}{l}18 \text { TPH ISGEC } \\
\text { Boiler }\end{array}$ & $\begin{array}{l}12 \text { TPH Thermax } \\
\text { Boiler }\end{array}$ \\
\hline 1 & Efficiency Evaluation Trial Period & $180 \mathrm{~min}$ & $230 \mathrm{~min}$ & $120 \mathrm{~min}$ \\
\hline 2 & Steam Quantity Generated, T & 47.2 & 72.8 & 18.66 \\
\hline 3 & Steam Pressure, $\mathrm{ka} / \mathrm{cm} 2$ & 28.71 & 27 & 14.47 \\
\hline 4 & Steam Temperature, ${ }^{\circ} \mathrm{C}$ & 415 & 328 & 191 \\
\hline 5 & Feedwater Temperature, ${ }^{\circ} \mathrm{C}$ & 99 & 75 & 94.1 \\
\hline 6 & Enthalpy of steam, Kcal/kg & 780.24 & 733.4 & 666.97 \\
\hline 7 & Coal consumed & 11.82 & 15.446 & 3.4 \\
\hline 8 & $\mathrm{NCV}$ of coal, Kcal/kg & 3878.5 & 4362.67 & 4145 \\
\hline 9 & Steam-Fuel ratio & 4 & 4.71 & 5.49 \\
\hline 10 & Direct method efficiency & 70.21 & 71.12 & 75.83 \\
\hline \multicolumn{5}{|c|}{ Flue gas Analysis Result: } \\
\hline 11 & $\mathrm{O} 2 \%$ & 8.30 & 7 & 14.20 \\
\hline 12 & Flue gases temperature after APH & 191 & 150 & 145 \\
\hline 13 & $\mathrm{CO} \%$ & 0.17 & 0.09 & 0.12 \\
\hline 14 & $\mathrm{CO} 2 \%$ & 11.38 & 12.74 & 6.16 \\
\hline 15 & Excess Air \% & 65.35 & 50 & 208.82 \\
\hline 16 & Ambient temp., ${ }^{\circ} \mathrm{C}$ & 35 & 30 & 35 \\
\hline 17 & Theoretical air required, $\mathrm{kg} / \mathrm{kg}$ of fuel & 5.53 & 5.89 & 6.45 \\
\hline 18 & Actual mass of air supplied $\mathrm{kg} / \mathrm{kg}$ of fuel & 9.14 & 8.83 & 19.92 \\
\hline 19 & $\mathrm{Cp}$ of flue gas, $\mathrm{Kcal} / \mathrm{kg}^{\circ} \mathrm{C}$ & 0.24 & 0.24 & 0.24 \\
\hline 20 & $\mathrm{Cp}$ of superheated steam, $\mathrm{Kcal} / \mathrm{kg}{ }^{\circ} \mathrm{C}$ & 0.45 & 0.45 & 0.45 \\
\hline 21 & Humidity factor, $\mathrm{kg} / \mathrm{kg}$ of dry air & 0.03 & 0.03 & 0.03 \\
\hline \multicolumn{5}{|c|}{ Coal Analysis Report: } \\
\hline 22 & $\%$ Carbon & 42.44 & 43.35 & 49.32 \\
\hline 23 & $\%$ Hydrogen & 2.92 & 3.64 & 3.28 \\
\hline 24 & $\%$ Nitrogen & 1.46 & 1.33 & 1.42 \\
\hline \multicolumn{5}{|c|}{ Indirect Method Efficiency Evaluation: } \\
\hline 25 & Heat loss due to dry flue gas loss, $\%$ & 8.30 & 5.88 & 11.82 \\
\hline 26 & $\begin{array}{l}\text { Heat loss due to evaporation of water formed } \\
\text { due to } \mathrm{H} 2 \text { in fuel, } \%\end{array}$ & 3.75 & 4.35 & 4.20 \\
\hline 27 & $\begin{array}{l}\text { Heat loss due to evaporation of moisture } \\
\text { present in fuel, } \%\end{array}$ & 2.33 & 1.23 & 1.77 \\
\hline 28 & Heat loss due to moisture present in air, $\%$ & 0.38 & 0.27 & 0.93 \\
\hline 29 & Heat loss due to partial conversion of $\mathrm{C}$ to $\mathrm{CO}$ & 0.79 & 0.36 & 1.11 \\
\hline 30 & Heat loss due to radiation losses \& other losses & 1.26 & 1.01 & 0.65 \\
\hline 31 & Heat loss due to unburnt in fly ash, $\%$ & 0.11 & 0.63 & 0.12 \\
\hline 32 & Heat loss due to unburnt in bottom ash, $\%$ & 2.59 & 1.88 & 0.59 \\
\hline 33 & Efficiency by indirect method & 80.48 & 84.31 & 78.82 \\
\hline
\end{tabular}

Above analysis mainly focuses on performance parameters like steam-fuel ratio, direct method efficiency (enthalpy division), indirect method efficiency (sources of losses and their quantification).
1. $\mathrm{O} 2 \%$ in flue gases and subsequently excess air for combustion is well within operation standards for Thermax and ISGEC boilers which found abnormal during walk-through audit. In case of $12 \mathrm{TPH}$ FBC Boiler, it is still at much higher level indicating maximum dry 
Pratik M. Joshi et.al. A case study on assessment performance and energy efficient recommendations for industrial boiler

flue gas loss. Amount of heat input and following Sankey Diagram: various losses are indicated in the

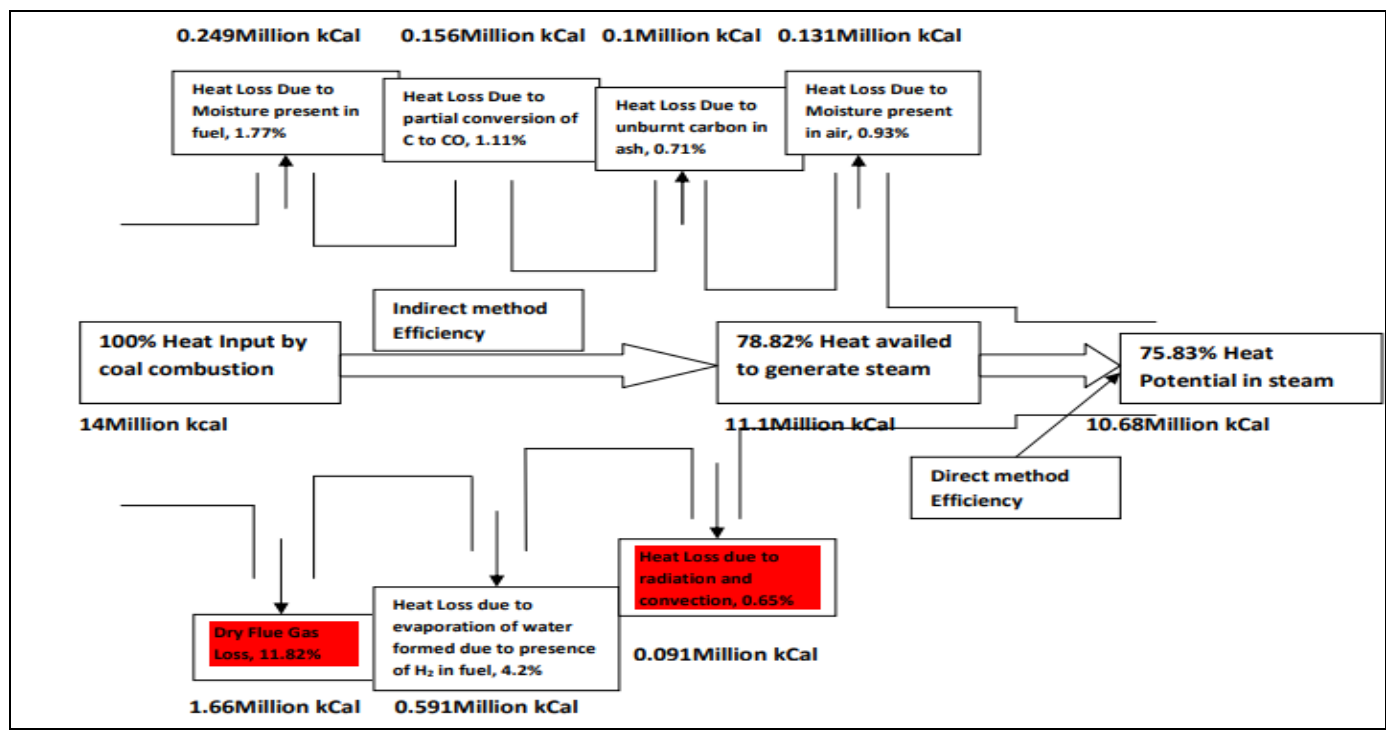

In the above diagram, heat flow of the boiler is indicated in terms of $\mathrm{kCal}$ (during trial period, i.e. for $2 \mathrm{Hrs}$ ) and percentage.

Heat losses right from combustion of coal to exit from air pre-heater outlet are also mapped.

The losses that can be controlled by standard operation practice and some modifications are indicated by red colour.

The dry flue gas loss can be controlled upto $6.4 \%$ with the help of excess air control. It will help to avail extra 5\% heat for steam generation.

2. For 18TPH travelling grate type Thermax boiler, at present there is no provision of heat recovery after economizer. So though $\mathrm{O} 2 \%$ and other related parameters are within standard, amount of losses seems to be high. Considering site conditions for waste heat recovery, detail suggestions are discussed in the report. It will also help to improve steam-fuel ratio and direct method efficiency of the boiler.

3. During ISGEC Boiler trial it was found that dampers of FD, ID and Secondary Air Fans are optimally set manually. All the measures for waste heat recovery are taken care already so maximum level of indirect method efficiency of the boiler is already achieved.

Observations and energy saving potential -

\begin{tabular}{|c|l|l|l|l|}
\hline $\begin{array}{c}\text { Sr. } \\
\text { No. }\end{array}$ & \multicolumn{1}{|c|}{ Description } & $\begin{array}{c}\text { Thermax } \\
\text { Boiler }\end{array}$ & $\begin{array}{c}\text { ISGEC } \\
\text { Boiler }\end{array}$ & \multicolumn{1}{|c|}{$\begin{array}{c}\text { FBC } \\
\text { Boiler }\end{array}$} \\
\hline 1 & Total Heat loss in KCal & 192703.03 & 178195.94 & 91110.19 \\
\hline 2 & $\begin{array}{l}\text { With proper Thermal Insulation savings in heat loss (Kcal @ 20\% of } \\
\text { total heat loss) }\end{array}$ & 38540.61 & 35639.19 & 18222.04 \\
\hline 3 & Calorific value of Coal, kcal/kg & 4200 & 4200 & 4300 \\
\hline 4 & Reduction in Coal consumption per day, kg & 200 & 200 & 95 \\
\hline
\end{tabular}

2. $O_{2} \%$ CONTROL IN FLUE GASES TO STANDARD VALUES -

\begin{tabular}{|c|c|c|c|c|c|}
\hline Boiler & $\begin{array}{c}\text { Present } \\
\mathbf{O}_{\mathbf{2}} \%\end{array}$ & $\begin{array}{c}\text { Standard } \\
\mathbf{O}_{\mathbf{2}} \%\end{array}$ & PresentS/F Ratio & $\begin{array}{c}\text { Improved } \\
\text { S/F Ratio }\end{array}$ & Annual Saving, Rs. \\
\hline Thermax Boiler & 8.3 & 7.5 & 3.9972 & 4.0200 & $11.21 \mathrm{Lac}$ \\
\hline ISGEC Boiler & 7 & \multicolumn{5}{|c|}{ Already at Optimum level } \\
\hline FBC Boiler & 14.2 & 7.5 & 5.4867 & 5.6437 & $13.36 \mathrm{Lac}$ \\
\hline
\end{tabular}

- For every $1 \%$ reduction in $\mathrm{O}_{2} \%$ in flue gases, there is approximately $0.6 \%$ rise in efficiency.
- Currently ISGEC Boiler $\mathrm{O}_{2} \%$ level is at optimum level so maximum possible indirect method efficiency is achieved. With close monitoring of $\mathrm{O}_{2} \%$ level in 
flue gases with the help of portable flue gas analyzer, present performance should be retained.

- In case of Thermax Boiler, there is a slight opportunity to lower the $\mathrm{O}_{2} \%$ level in flue gases which will enhance the efficiency from $70.21 \%$ to $70.61 \%$ and consequently s/f ratio from 3.9972 to 4.0200. For FBC boiler, efficiency can be raised upto $78 \%$ which reflects in the improvement of s/f ratio upto 5.6437.

- Annual saving associated with $\mathrm{O} 2 \%$ Control in flue gases is tabulated above for all the boilers.

$\mathrm{O}_{2} \%$ Control in flue gases can be implemented with two methods:

1. Manual damper control of FD, ID fans of boilers-

Periodic checking of $\mathrm{O}_{2} \%$ in flue gases should be carried out with the help of portable flue gas analyzer. According to measured value, the dampers can be adjusted to maintain the standard value.

2. Provision of VFDs to FD and ID fans of the boilers-

With the installation of VFD for FD and ID fans of both the boilers, automatic control of $\mathrm{O}_{2} \%$ in flue gases can be achieved. It should be in closed loop for which $\mathrm{O}_{2} \%$, furnace draft pressure can be given as feedback parameters.

\begin{tabular}{|l|c|c|c|}
\hline \multicolumn{1}{|c|}{ Boiler } & Fan & Capacity & Cost of VFD \\
\hline Thermax Boiler & FD & $30 \mathrm{HP}$ & $1,35,000$ \\
\hline Online $\mathrm{O}_{2}$ monitoring equipment & $1,25,000$ \\
\hline \multicolumn{3}{|c|}{ Total cost associated } & $\mathbf{6 , 8 5 , 0 0 0}$ \\
\hline Boiler & Fan & Capacity & Cost of VFD \\
\hline FBC Boiler & FD 1 & $30 \mathrm{HP}$ & $1,35,000$ \\
\hline Online $\mathrm{O}_{2}$ monitoring equipment & $1,25,000$ \\
\hline \multicolumn{3}{|c|}{ Total cost associated } & $\mathbf{6 , 8 0 , 0 0 0}$ \\
\hline
\end{tabular}

\section{EFFECT OF COAL ADDITIVE}

Working Principle of coal additive

1. It reduces ignition temperature from $454^{\circ} \mathrm{C}$ to $316^{\circ} \mathrm{C}$ due to which faster heat generation is achieved in lesser time.

2. It regulates the release of carbon due to which uniform \& synchronized heat generation takes place and heat intensity increases.

3. Metallic based compounds in carbonizer ionize the air between gas particles which improves heat transfer rate.

To evaluate the effect of coal additive, we conducted efficiency trial on Thermax travelling grate type boiler. We observed avg. $7 \%$ increase in s/f ratio of Thermax Boiler.

With application of coal additive to both Thermax and ISGEC boiler, following savings can be achieved.

\begin{tabular}{|c|c|c|c|c|}
\hline Sr. No. & Boiler & $\begin{array}{c}\text { Present Monthly } \\
\text { Coal Consumption, T }\end{array}$ & $\begin{array}{c}\text { Revised Monthly } \\
\text { Coal Consumption, T }\end{array}$ & $\begin{array}{c}\text { Associated Annual } \\
\text { Savings, Rs. }\end{array}$ \\
\hline 1 & Thermax Boiler & 2810 & 2615 & 1189500 \\
\hline 2 & ISGEC Boiler & 2560 & 2380 & 1093120 \\
\hline \multicolumn{3}{|r|}{ Total Monthly Savings due to Coal Additive } \\
\hline
\end{tabular}

- The coal additive mixing proportion recommended by manufacturer is $1.1 \mathrm{~kg}$ of coal additive/T of coal.

- Revised monthly coal consumption for both the boilers due to coal additive will be 4995 T. So, the required monthly coal additive quantity will be $5495 \mathrm{~kg}$ which costs around Rs.12.1Lacs (considering Rs 220/kg of coal additive).

- The net saving due to coal additive is Rs. 10.73Lacs.

\section{ASSESSMENT OF ECONOMIZER PERFORMANCE-}

Economizer efficiency is assessed based on heat quantity available in the flue gases and heat absorbed by feedwater while passing through economizer.

For FBC Boiler, there is no provision for temperature measurement of feedwater as well as flue gases before and after water optimizer. It should be made so that the performance evaluation of water optimizer and air pre-heater can be carried out.

For Thermax and ISGEC boiler, the calculations are shown below: 
Pratik M. Joshi et.al. A case study on assessment performance and energy efficient recommendations for industrial boiler

\begin{tabular}{|c|l|c|c|}
\hline Sr. No. & \multicolumn{1}{|c|}{ Description } & Thermax Boiler & ISGEC Boiler \\
\hline 1 & Steam Generated during efficiency trial period, T & 47.2 & 72.8 \\
\hline 2 & Coal Consumption for steam generation, T & 11.82 & 15.446 \\
\hline 3 & Actual mass of air supplied for combustion, $\mathrm{kg} / \mathrm{kg}$ of fuel & 9.14 & 8.83 \\
\hline 4 & Economizer flue gas inlet temperature, ${ }^{\circ} \mathrm{C}$ & 312 & 316 \\
\hline 5 & Economizer flue gas outlet temperature, ${ }^{\circ} \mathrm{C}$ & 191 & 176 \\
\hline 6 & Economizer feed-water inlet temperature, ${ }^{\circ} \mathrm{C}$ & 95 & 75 \\
\hline 7 & Economizer feed-water outlet temperature, ${ }^{\circ} \mathrm{C}$ & 146 & 100 \\
\hline 8 & Cp of flue gases, $\mathrm{kcal} / \mathrm{kg}{ }^{\circ} \mathrm{C}$ & 0.26 & 0.26 \\
\hline 9 & Grate Ash Quantity measured during efficiency trial period, $\mathrm{kg}$ & 2788 & 3464.7 \\
\hline 10 & Heat available in flue gases, $\mathrm{kCal}$ & 3682921.53 & 4985215 \\
\hline 11 & Heat absorbed by steam in the economizer, $\mathrm{kCal}$ & 2537472 & 1820000 \\
\hline 12 & Efficiency of economizer, $\%$ & $68.9 \%$ & $36.5 \%$ \\
\hline 13 & Additional heat available if efficiency reaches to $75 \%$ & 220975.3 & 1919307 \\
\hline 14 & Daily Coal Saving, $\mathrm{kg}$ & 420 & 1680 \\
\hline 15 & Annual Savings, $\mathrm{Rs}$ & 38.42 & \\
\hline
\end{tabular}

The standard efficiency of any heat exchanger is around $80 \%$ and above.

- Efficiency of Thermax Boiler economizer is quietly satisfactory but can be improved with the help of proper cleaning by effective use of soot blowers, avoiding scale and sludge formation on water side.

- In case of ISGEC Boiler economizer, efficiency is very poor. Still the low temperature of flue gases at economizer outlet is observed which might be due to air ingress in the economizer path or some other openings.

- This should be immediately prohibited to avail maximum waste heat recovery and the above-mentioned precautions for Thermax Boiler should be followed for ISGEC boiler also.

\section{WASTE HEAT RECOVERY OPTIONS FOR THERMAX BOILER:}

For Thermax boiler, flue gas outlet temperature out of economizer is 191Deg C. In flue gas path, after economizer there is no provision of heat recovery due to which losses quantified in the indirect method efficiency calculations are much higher compared to ISGEC boiler where air preheater is installed for waste heat recovery.

\section{Water optimizer after economizer in flue gas path-}

Considering space constraint for Thermax boiler, we suggest installation of water optimizer. Compared to duct size for air handling, water pipe size is much smaller and is feasible to install in the available space. For Thermax Boiler, feedwater used is condensate recovered from the system and its temperature is around $93-99^{\circ} \mathrm{C}$.

After installation of water optimizer, the feed-water temperature at outlet of it will reach in the range of 110 to $120^{\circ} \mathrm{C}$ depending on the temperature of recovered condensate. To retain its water phase, the system needs to pressurize up to 2 to $2.5 \mathrm{~kg} / \mathrm{cm}^{2}$ in place of existing atmospheric system. We propose a pressurized tank in between water optimizer and economizer. The schematic of the system will be as follows:

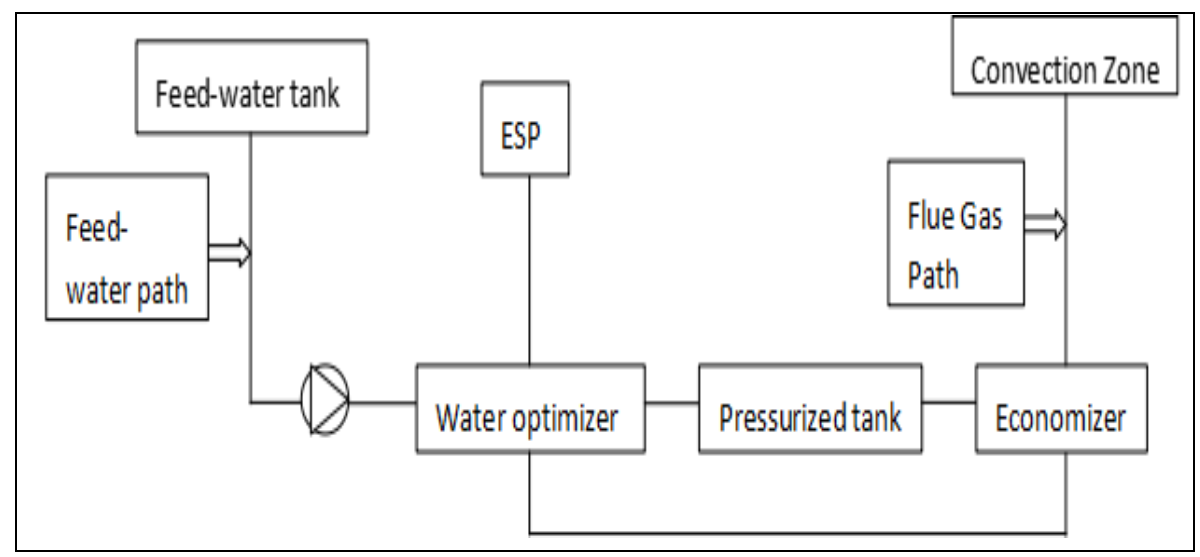


Pratik M. Joshi et.al. A case study on assessment performance and energy efficient recommendations for industrial boiler

\section{Savings associated with above proposed system:}

Coal Consumption / Hr.-3.94T

Heat Available for waste heat recovery when $\mathrm{O}_{2} \%$ is controlled up to $7.5 \%$ $(\mathrm{kCal} / \mathrm{Hr})-342400$.

Waste heat recovery possible $(\mathrm{kCal} / \mathrm{Hr})-$ 256800

Coal Saving (kg/hr.)-60

Annual Saving Cost Rs. -26.35Lacs

Investment required Rs. - 20Lacs (Including provision of pressurized tank) Payback period-9 to 10 months
OR

\section{Secondary Economizer -}

Another option for waste heat recovery is provision of secondary economizer in between existing economizer and ESP. But due to arrangement of pressure piping, the structure needs an IBR approval.

So, the option is slightly costlier than water optimizer. The schematic for secondary economizer will be as follows:

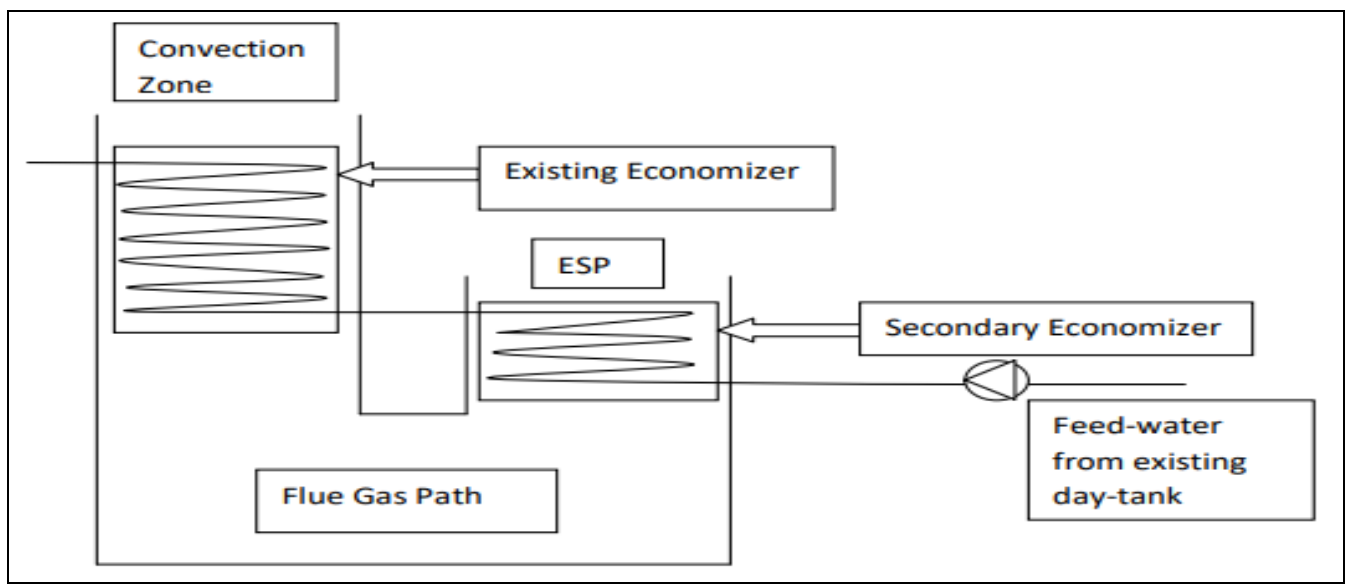

ENERGY

\section{OPPORTUNITIES-}

1. Condensate recovery of the plant is around $80-85 \%$ which is at its best level.

2. Ultrasonic inspection of steam traps is carried out during which no leakages were observed. All the steam traps in steam distribution system are working properly.

3. If $\mathrm{O} 2 \%$ control is achieved with the help of VFDs, electrical energy consumption for boiler auxiliaries will be reduced.

\section{CONCLUSION}

With the help of various tests conducted and site measurements we have reached to following points:

$\mathrm{O}_{2} \%$ in flue gases is observed several times to optimize the dry flue gas loss for all the boilers. While detail analysis of ISGEC and Thermax Boiler, a level of $\mathrm{O}_{2} \%$ was better than observed during walkthrough audit. Foe FBC boiler it was far away from the required value. It can be finetuned manually as well as with the help of automation.

Savings and Investments associated with this remedy are tabulated in the following table.

- Thermography survey of boiler surfaces is carried out to estimate the radiation and other losses. The regions where insulation is damaged or absent are noted and investment required for repairing of the insulation is enlisted. Total annual savings after insulation repairing is $8.48 \mathrm{Lac}$ and investment is around Rs. 6.31Lac.

- Economizer performance of both ISGEC and Thermax boiler can be improved with the help of suggested measures. It will help to save Rs. 38.42Lac annually and investment or maintenance cost is negligible.

- As there is no provision of air pre-heater for Thermax Boiler, there is an 
Pratik M. Joshi et.al. A case study on assessment performance and energy efficient recommendations for industrial boiler

opportunity for waste heat recovery. Considering space constraint, we have suggested feed-water pre-heating by absorbing heat from flue gases. The two options are discussed in detail in the respective section.
Annual savings associated with this opportunity is Rs. 26.35Lacs.

During boiler assessment period, a significant control on daily boiler operation is observed. Considering age of the boiler, the extent of control can be rarely seen elsewhere.

\begin{tabular}{|c|c|c|c|c|c|}
\hline $\begin{array}{l}\text { Sr. } \\
\text { No. }\end{array}$ & $\begin{array}{l}\text { Energy saving } \\
\text { opportunity }\end{array}$ & $\begin{array}{l}\text { Possible Saving in Rs. } \\
\text { Lacs/Annum }\end{array}$ & $\begin{array}{c}\text { Estimated investment } \\
\text { in Rs. Lacs }\end{array}$ & $\begin{array}{l}\text { Payback } \\
\text { in Months }\end{array}$ & Category \\
\hline \multicolumn{6}{|c|}{ Identified saving opportunities during energy assessment } \\
\hline \multirow[t]{4}{*}{1.} & $\begin{array}{l}\mathrm{O}_{2} \% \text { control in flue gases to standard } \\
\text { values } \\
\text { Benefits } \\
\text { Excess Air Control } \\
\text { Optimization of dry flue gas loss } \\
\text { Boiler Efficiency } \\
\text { Improvement }\end{array}$ & $\begin{array}{c}\text { Thermax - } \\
11.21\end{array}$ & $\begin{array}{l}\text { Manual Damper } \\
\text { Control - } \\
\text { No Investment }\end{array}$ & 7 months & No Cost \\
\hline & & ISGEC - Nil & & & \\
\hline & & $\mathrm{FBC}-13.36$ & Installation of VFD -13.65 & & $\begin{array}{l}\text { Medium } \\
\text { Cost }\end{array}$ \\
\hline & & Total -24.57 & & & \\
\hline \multirow[t]{4}{*}{2.} & $\begin{array}{l}\text { Prevention of convection and radiation } \\
\text { heat losses by application of insulation } \\
\text { on boiler body }\end{array}$ & Thermax -3.66 & 1.93 & 9 months & Low cost \\
\hline & & ISGEC - 3.66 & 2.34 & & \\
\hline & & $\mathrm{FBC}-1.16$ & 2.04 & & \\
\hline & & Total -8.48 & 6.31 & & \\
\hline \multirow[t]{2}{*}{3.} & $\begin{array}{l}\text { Waste Heat Recovery } \\
\text { Options for Thermax Boiler: } \\
\text { a) Water optimizer after economizer in } \\
\text { flue gas path }\end{array}$ & 26.35 & 20 & $\begin{array}{c}\text { 9-10 } \\
\text { Months }\end{array}$ & High Cost \\
\hline & $\begin{array}{l}\text { b) Secondary } \\
\text { Economizer }\end{array}$ & & $\begin{array}{l}\text { Will depend on material } \\
\text { steam pressure and } \\
\text { selected material }\end{array}$ & & \\
\hline 4. & Economizer Performance Improvement & 38.42 & $2-3$ & Negligible & Low cost \\
\hline \multicolumn{2}{|r|}{ Total } & 97.82 & 42.96 & & \\
\hline \multicolumn{6}{|c|}{ Verified Saving from plant operation practice: } \\
\hline \multicolumn{6}{|c|}{$\begin{array}{l}\text { Annual cost saving possible due to use of coal additive is Rs. 2.74Crore. } \\
\text { The coal additive cost associated to above savings is Rs. 1.45Crore so the net annual saving due to use of coal additive will be Rs. } \\
1.28 \text { Crore. }\end{array}$} \\
\hline
\end{tabular}

\section{Acknowledgement: None}

Conflict of Interest: None

\section{Source of Funding: None}

\section{REFERENCES}

1. Miroslav Kljajić, Dusan Gvozdenac, "Assessment of boiler's operating performance in different energy sectors in the province of Vojvodina", 'Thermal Science', (January 2012).

2. Tai Lva, Linghao Yua, Jinmin Songb, "A Research of Simplified Method in Boiler Efficiency Test', '2012 International Conference on Future Electrical Power and Energy Systems'.

3. Shizhe Li, Yinsong Wang, "Performance Assessment of a Boiler Combustion Process Control System Based on a Data-Driven
Approach", 'Processes' Published: 19 October 2018.

4. Acharya Chirag, Prof. Nirvesh Mehta, Prof. Jaspal Dabhi, "Research paper on Analysis of Boiler losses to improve Unit heat rate of coal fired thermal power plant", 'International Journal of Advance Engineering and Research Development (IJAERD)', Volume 1, Issue 5, May 2014, e-ISSN: 2348 - 4470, print-ISSN:23486406.

5. Trushar Patel, Divyesh Patel, "Energy Analysis and Efficiency Assessment of Water Tube Boiler", 'IOSR Journal of Mechanical and Civil Engineering (IOSRJMCE)', e-ISSN: 2278-1684, p-ISSN: 2320334X, Volume 11, Issue 3 Ver. VI (MayJun. 2014), PP 65-69.

6. Yoalbys Retirado-Mediaceja, Yanán Camaraza-Medina, Andrés A. SánchezEscalona, Héctor L. LaurencioAlfonso, 
Pratik M. Joshi et.al. A case study on assessment performance and energy efficient recommendations for industrial boiler

Marcelo F. Salazar-Corrales, Carlos Zalazar-Oliva1, "Thermo-Exergetic Assessment of the Steam Boilers Used in a Cuban Thermoelectric Facility", 'International Journal of Design \& Nature and Ecodynamics' Vol. 15, No. 3 June 2020, pp. 291-298.

7. G.J. Nakoneczny, "Boiler Fitness Survey for Condition Assessment of Industrial Boilers", 'Babcock \& Wilcox'.

How to cite this article: Joshi PM, Shinde ST, Chaudhary K. A case study on assessment performance and energy efficient recommendations for industrial boiler. International Journal of Research and Review. 2021; 8(4): 61-69. DOI: https://doi.org/ 10.52403/ijrr.20210410 